\title{
ONION PROPERTIES CHANGES AS AFFECTED BY DIFFERENT STORAGE CONDITIONS
}

\author{
Hatem $^{1}$, M. H.; Shehata ${ }^{2}$, S. A.; AbdEl-hay ${ }^{1}$, Y. B.; Karima ${ }^{2}$, \\ F. AbdEl-Gwad and Abaker'3 , B. A
}

\begin{abstract}
In the tropics, onion (Allium cepa L.) bulbs are usually stored in shelters under ambient conditions resulting in severe losses. Storage conditions play an important role in affecting the physical, chemical, and biological change of onion bulbs. The objective of this work was to study the properties of onion bulbs as affected by storage conditions. Three different storage conditions were used namely, forced ventilated, natural ventilated and traditional storage systems. The properties of the onion bulbs that to be studied were equatorial and polar diameters, hardness, dry matter, total soluble solids, total carbohydrates. The results indicated that, the average temperature in center of onion pile during the storage period ranged between 16.73 to $28.61{ }^{\circ} \mathrm{C}$ for the forced ventilated, where it was ranged between 18.18 to $31.03{ }^{\circ} \mathrm{C}$ for the natural ventilated, while in traditional storage system ranged between 19.52 to $32.93{ }^{\circ} \mathrm{C}$. The equatorial and polar diametre change ranged between 69.33-73.44, 68.56-72.78 and 66.2273.11 mm and 53.22-57.11, 55.22-59 and 49-57.56mm for the forced ventilated, natural ventilated and traditional storage system, respectively, and the lowest changes in equatorial and polar diameter were 1.1 and $1.17 \%$, respectively, which recorded in traditional storage system, the highest value of hardness was recorded the onion stored in forced ventilated and natural ventilated (17.20 and $17.07 \mathrm{~kg}_{f}$ ), respectively. The highest TSS\% was obtained in forced ventilated $14.40 \%$ and highest mean of dry matter contents recorded when the bulbs stored in natural ventilated and forced ventilated (15.94, 15.89\%), respectively, On the other hand, bulbs after 7 months of storage showed highest carbohydrates mean percentage in forced and natural ventilated (8.08 and $8.05 \%)$, respectively.
\end{abstract}

Keywords: Onion bulbs, temperature, relative humidity, forced ventilation, natural ventilation, equatorial and polar diameters, hardness, total soluble solids, carbohydrates

\footnotetext{
${ }^{1}$ Agric. Eng. Dept., Fac. of Agric., Cairo University, Egypt

${ }^{2}$ Veg. Dept., Fac. of Agric., Cairo University, Egypt

${ }^{3}$ Agric. Eng. Dept., Fac. of Agric.,Zalingei University, Sudan
} 


\section{INTRODUCTION}

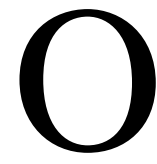
nion (Allium cepa) is a delicate and perishable commodity and difficult to store for a long period at room temperature, especially in tropical and subtropical countries, due to its high water content and many other factors associated with it (Curran and Proctor, 1990). They added that, refrigerated storage facilities are often too expensive for farmers in these regions. Therefore, onion is stored mostly in shelters at ambient conditions under tropical conditions.

Bhatnagar et al. (1989) suggested that the designing of low cost farm level storage structure capable of reducing losses in stored onion could be helpful in encouraging onion storage by the farmers. The losses, where no bottom ventilation is provided, are estimated to the extent of 30 to $35 \%$ due to physiological loss in weight, 10 to $12 \%$ by decay and 8 to $12 \%$ on an account of sprouting, depending upon the relative humidity and temperature during the rainy season (Maini and Chakrabarti, 2000).

Many biochemical changes take place during storage, and some of them are linked to bulbs respiration. These changes can be in water (Corgan and Kedar, 1990) and carbohydrate content, flavor compound concentration, and plant growth regulators (Chope et al., 2006). The storage of onion can be extended by using optimum temperatures, but it entails higher costs and may cause biochemical changes that degrade the storage product quality, for example, lowering of the product quality (Rapusas, 1995).

It is visible that the hardness of the fresh onion is very much higher than that of the freeze-dried, about $15 \mathrm{~N}$ in the fresh against about $3 \mathrm{~N}$ in the dried sample. The average hardness of the fresh onion was found to be $12.87( \pm 2.24) \mathrm{N}$ and that for the freeze-dried was $3.50( \pm 0.71) \mathrm{N}$ (Raquel and Maria, 2010).

Onion bulbs were best cured in the artificial curing of 10 to 14 hours at $45^{\circ} \mathrm{C}$ with air flow rate of $222 \mathrm{~m} 3$ per minute compared to 8 to 10 days of sun curing and also reported the hardness of onion bulb had significant increase (9.75 to $10.5 \mathrm{~kg} / \mathrm{cm}^{2}$ ) with curing. The curing operation resulted in development of dull red colour from dull purple red of cured bulbs (Satish and Ranganna, 2002). 
The higher TSS (11.27\%) recorded in bulbs cured with foliage as compared to bulbs cured without foliage $(9.36 \%)$ is in agreement with Kaynas et al. (1995). The per cent dry matter and TSS increased during storage from 11.4 to 12.3 and 10.6 to 11.9 , respectively, but reducing sugar content decreased from 3.47 to 2.35 per cent. However, the non-reducing sugar content of onion bulbs increased from 5.26 to 6.61 per cent during six months of storage (Patil and Kale, 1998). Magadum (1981) observed that the cultivars with higher values of non-reducing sugar also recorded higher percentage of TSS and dry matter content but lower percentage of reducing sugar. During six months storage period, the dry matter content, TSS and non-reducing sugar content were increased while reducing sugars and protein contents were reduced (Patil, 1983).

The quantitative changes in the carbohydrate constituents are the most important biochemical changes which occur during the storage of onion grown in temperate regions (Rutherford, 1981). Croci et al. (1995) observed the carbohydrate content remained constant throughout the storage period (180 days) and storage duration had no significant effect on the ascorbic acid content of onion bulbs. Bahnasawy et al. (2004) investigated the physical and mechanical properties of onion bulbs of Giza 20. They found that, the onion bulbs are spherical in shape, and the equatorial and polar diameter ranged from $5.12 \pm 0.33$ to $6.20 \pm 1.5 \mathrm{~cm}$, the density ranged from $1.04 \pm 0.09$ to $1.11 \pm 0.15 \mathrm{~g} / \mathrm{cm}^{3}$, and crushing load ranged from 400 to $780 \mathrm{~N}$, and penetration load also ranged from 27.6 to 45.5 N. Maw et al. (1996) found that the force to crush an onion had a mean of $26.4 \pm 4.9 \mathrm{~N}$, with a maximum of $40.9 \mathrm{~N}$ and a minimum of $13.8 \mathrm{~N}$.

From the previous studies, it was found that there is no sufficient literature on the change of the onion bulbs properties during storage; therefore, low cost farm level storage is required to be developed to extend the shelf life of fresh vegetable products, such as onion to maintain properties of fresh onion. This study aimed to investigate the effect of storage conditions on the onion properties during storage under three different storage conditions namely forced ventilated, natural ventilated and traditional storage systems. The properties of the onion bulbs that to be studied are equatorial and polar diameters, hardness, total soluble solids, dry matter and total carbohydrates. 


\section{EXPERIMENTAL PROCEDURES}

\section{Onion bulbs:-}

Onion bulbs c.v. of Giza 20 was produced at Waddy Elnatron Farm, Agricultural Experimental Station of the Faculty of Agriculture, Cairo University, according to the recommendations of standard agricultural practices during the winter seasons of 2013/2014. The crop was harvested on June 2013 when about $75-80 \%$ of the plants fell down and became matured. After harvest, bulbs were kept under a shade for 7 days in field and for other 7 days in shaded shelter for curing. The bulbs inspected and sound bulbs were excluded after curing. Then, for storage studies, $630 \mathrm{~kg}$ bulbs were delivered to the Agricultural Engineering Department, Faculty of Agriculture Cairo University to store under different bins. Bulbs were stored for 7 months, at monthly intervals. The average moisture content of onion bulbs after harvest was $84 \pm 1.31 \%$.

\section{Storage bins:-}

The storage bins were designed to use local materials and to be simple to construct. It is an ordinary farm level storage bin made of wooden pole frame, woven wheat straw in wall, concrete floor covered with $10 \mathrm{~cm}$ straw above the floor and roof was covered with plywood to protect against rain and direct sunlight. The unit size is approximately $2 \mathrm{~m}$ long, $1.5 \mathrm{~m}$ wide and $3.0 \mathrm{~m}$ height as shown in figures 1 and 2 .

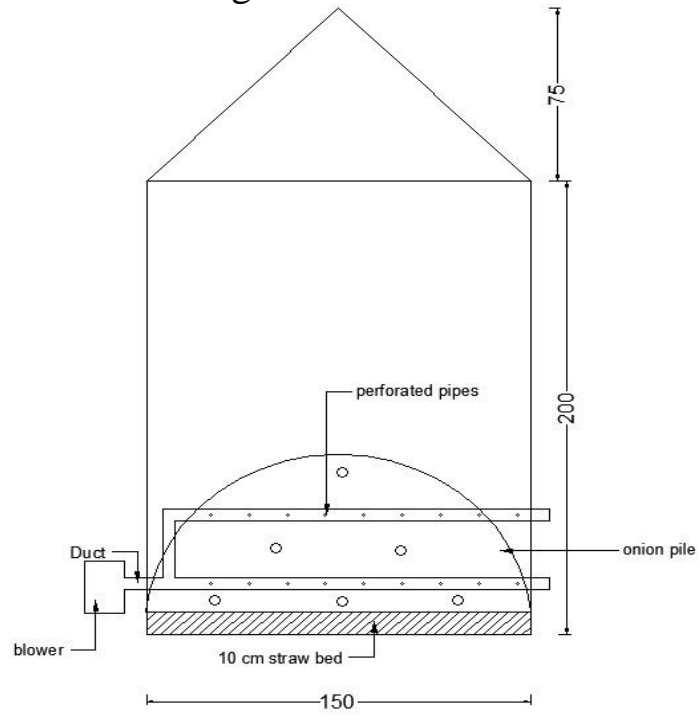

(A)

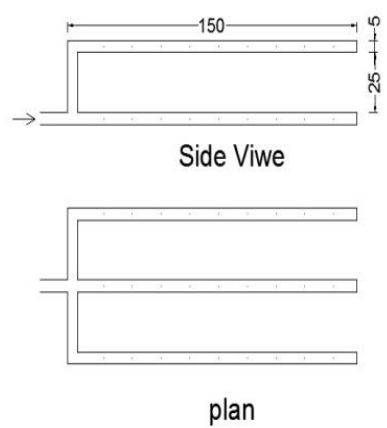

(B)

Figure 1. Diagram showing the ventilated system (A), chamber (B), onion pile and locations of sensors at forced ventilated system 


\section{Ventilated system:-}

1- Forced ventilation: The ventilated system consist of a blower that was used to provide the ventilation air (delivering based on recommended fan sizes" of $0.047 \mathrm{~m}^{3} \mathrm{~s}^{-1} \mathrm{t}^{-1}$ ), inlet air velocity was measured using thermoanemometer (model 407123 mode in Taiwan) located on the air supply pipe (50 $\mathrm{mm}$ diameter manifold) which distributes the air inside the onion pile through perforated laterals located at different depths 15, 25, and $40 \mathrm{~cm}$. The holes $(1 \mathrm{~cm}$ in diameter) were uniformity distributed on the laterals surface, 4 holes every $10 \mathrm{~cm}$ alternatively placed on the four sides of the pipe.

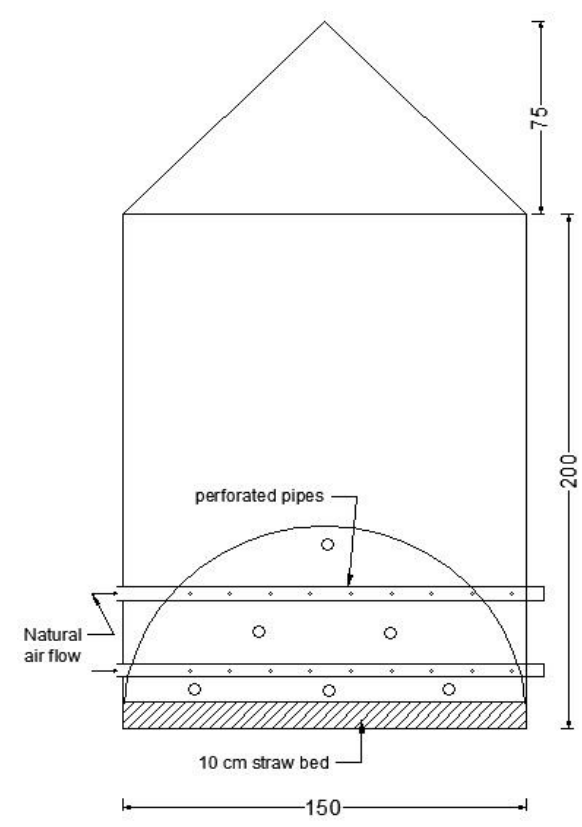

(C)

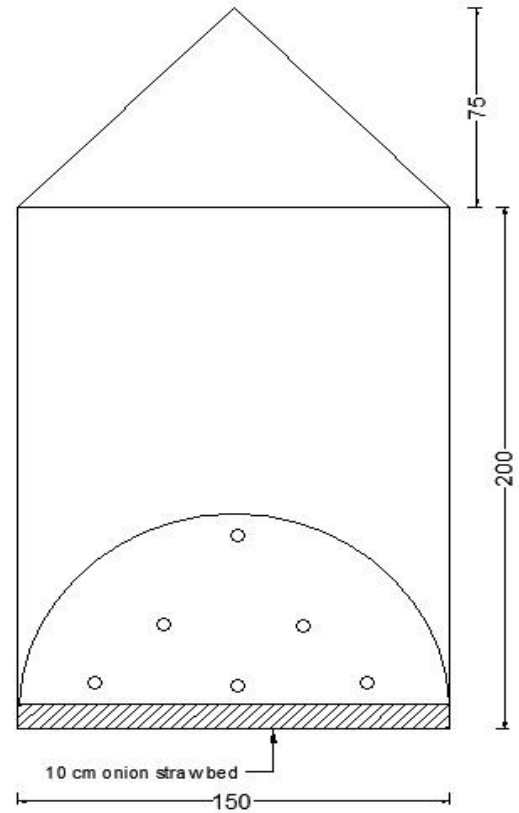

(D)

Figure 2 Diagrams showing the natural ventilation system (C), traditional system (D), onion pile and locations of sensors

2- The ventilation regimes used in the natural ventilated storage was based on the prevailing ambient conditions. Air was free to circulate around the bins at all times, and the same pipes and depths at forced ventilated were used, to distribute air naturally inside the onion pile through perforated 
holes so as to achieve a relatively stable temperature and $\mathrm{RH}$ within onion pile, natural ventilation is induced by wind pressure and thermal buoyancy forces, the thermal buoyancy occurs in naturally ventilated storage bin dependent of the outside wind conditions.

3- While in traditional system there were no pipes within onion pile. The bins were carefully loaded with loose bulbs.

Measuring devices:-

1- A drying oven (Memmert GMBH + CO. KG D-91126 nenntemp. $300^{\circ}$

C $220 \mathrm{~V}$ fresh airs, Made in Germany) at $70^{\circ} \mathrm{C}$ until constant weight was obtained.

2- An electronic sensitive balance (Metler PM600, max 610g with an accuracy $\pm 0.01 \mathrm{~g}$ made in Switzerland) was used to weight samples during the experiment.

3- A Hand Digital Refractometer (SR-95 made in UK) was used to measure the total soluble solids of onion bulbs.

4- A hand penetrometer (Force gauge model M4-200, 100kgf, 1000N, 1kN, Mode in USA) was used to measure the penetration resistance of the onion bulbs.

5- A Data logger (Labjack U3-HV, LabJack corporation 3232S vance St STE 100 Lakewood, CO 80227USA, serial number 320044578) was used during the period to measure the daily temperature and relative humidity at various locations in onion pile.

6- A blower (Milano centrifugal fan, model No. 130FLJ1, power $0.085 \mathrm{~kW}$, flow $216 \mathrm{~m}^{3} / \mathrm{h}$, made in China), was used to provide the ventilation air.

7- A thermo-anemometer (model 407123 Made in Taiwan) was used to measure the airflow rate

\section{Procedures:-}

\section{Temperature and RH measurements:}

During the period of experimentation, the temperature and relative humidity were recorded 4 times a day (at 6:00 a. m., 12:00 noon, 6:00 p. m., and 12:00 a. m.) at various locations within onion pile, with the help of Data logger (Labjack U3-HV). Six temperature and RH sensors were placed in each onion pile in the depth of 15,40 and $60 \mathrm{~cm}$ (top) in the storage bins during loading. All sensors were connected to a Data Logger programmed to collect data every $30-\mathrm{min}$. The ventilation was used during 
$7 \mathrm{am}$ to 10 am and $6 \mathrm{pm}$ to $8 \mathrm{pm}$ then stopped. All sensors were calibrated before, during and after the trials. The data were analyzed weekly.

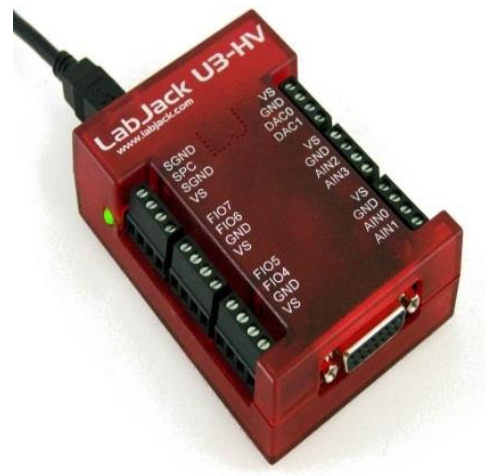

Figure 3 Data logger

\section{Measurement of physical and mechanical properties:-}

Three good quality bulbs from each plot were randomly sampled at the beginning of storage for measuring the change in equatorial and polar diameters, hardness, TSS, dry matter and total carbohydrate at Laboratory of (CIEV) Faculty of Agriculture, Cairo University, Egypt.

\subsection{Hardness:}

The hardness of onion bulbs was measured using a hand penetrometer which measures the penetration resistance of the bulbs, which was the force required for pushing a probe into a product to a depth that causes irreversible crushing. It was given as an indicator of the mechanical strength of the onion to withstand mechanical harvesting and postharvest handling. A head of a flat-end probe $(8.0 \mathrm{~mm}$ diameter) was used to measure the penetration resistance.

\subsection{Total soluble solids and dry matter content:-}

Total soluble solids (TSS) were determined by squeezing the juice from fresh onion tissues using a garlic press onto a hand-held refractometer. For each storage batch, 3 onion bulbs (without sprouts) were cut up and mixed together. Total soluble solid content was determined. The remaining bulbs were sliced and a $100 \mathrm{~g}$ samples were then dried at $70^{\circ} \mathrm{C}$ for 4 days and the percentage of dry matter content was determined according to the method 
of AOAC (1995). The initial weight of 5 kilograms bulbs per bag was determined before storage and average bulb weight was calculated.

\subsection{Total carbohydrates percentage:-}

Total carbohydrates percentages were determined according to the method described in A. O. A. C. (1990).

\section{RESULTS AND DISCUSION}

\section{Temperature and relative humidity change during the storage periods under different conditions:-}

The storage environment during the period of storage plays an important role in the storage life and losses during the storage. July and August months were chosen as the hotest months in the years, while December and January were taken as the coldest months in the year as example for the environmental factors. Temperatur and relative humidity were recorded at various locations in all storage bins over the storage periods.

\subsection{Temperature:}

Data given in table 1 shows an example of the temperature recorded in the onion pile of storage systems under study (forced ventilated, natural ventilated and traditional storage systems) during the storage period. The average temperatures during the month of July were 28.53, 30.50 and $32.66{ }^{\circ} \mathrm{C}$ for forced ventilated, natural ventilated and traditional storage systems, respectively, while, they were $26.22,27.34$ and $29.28^{\circ} \mathrm{C}$ during the month of August for the same previous order. On the other hand, the average temperature during the month of December were 24.23, 24.67 and $25.90{ }^{\circ} \mathrm{C}$ for forced ventilated, natural ventilated and traditional storage systems, respectively, while, they were $16.99,20.02$ and $20.10^{\circ} \mathrm{C}$ during the month of January for the same previous order.

It could be seen that the variations between the average temperature recorded during the months of July, August, December and January were $4.13,3.05,1.67$ and $3.11^{\circ} \mathrm{C}$ for the forced ventilated, natural ventilated and traditional storage systems, respectively. 
Table 1. the average monthly temperature recorded in the center of onion pile at different times of the day for the forced ventilated, natural ventilated and traditional storage systems.

\begin{tabular}{|c|c|c|c|c|}
\hline Month & Time & Forced ventilated & Natural ventilated & Traditional storage \\
\hline \multirow{5}{*}{ July } & $12: 00 \mathrm{am}$ & 28.48 & 30.51 & 32.72 \\
\cline { 2 - 5 } & $6: 00 \mathrm{am}$ & 28.46 & 30.18 & 31.40 \\
\cline { 2 - 5 } & $12: 00 \mathrm{pm}$ & 28.61 & 30.26 & 32.33 \\
\cline { 2 - 5 } & $6: 00 \mathrm{pm}$ & 28.56 & 31.03 & 32.93 \\
\hline August & $12: 00 \mathrm{am}$ & 26.45 & 26.99 & 29.34 \\
\cline { 2 - 5 } & $6: 00 \mathrm{am}$ & 26.20 & 28.36 & 29.20 \\
\cline { 2 - 5 } & $12: 00 \mathrm{pm}$ & 26.93 & 27.20 & 29.20 \\
\cline { 2 - 5 } & $6: 00 \mathrm{pm}$ & 25.29 & 26.79 & 29.30 \\
\hline December & $12: 00 \mathrm{am}$ & 24.30 & 24.69 & 26.11 \\
\cline { 2 - 5 } & $6: 00 \mathrm{am}$ & 24.10 & 24.67 & 25.69 \\
\cline { 2 - 5 } & $12: 00 \mathrm{pm}$ & 24.27 & 24.26 & 26.35 \\
\cline { 2 - 5 } & $6: 00 \mathrm{pm}$ & 24.25 & 25.07 & 21.06 \\
\hline January & $12: 00 \mathrm{am}$ & 17.12 & 20.83 & 20.20 \\
\cline { 2 - 5 } & $6: 00 \mathrm{am}$ & 17.09 & 20.52 & 19.52 \\
\cline { 2 - 5 } & $12: 00 \mathrm{pm}$ & 17.04 & 20.56 & 19.63 \\
\cline { 2 - 5 } & $6: 00 \mathrm{pm}$ & 16.73 & & \\
\hline
\end{tabular}

Figure 5 shows the temperature distribution at the forced ventilated, natural ventilated and traditional storage systems in the onion piles at various locations at 12pm during the first month of storage (July). It can be noticed that the temperature gradient in forced ventilated (A) increased from the bed (lower temperature) towards the top (higher temperature) of the onion pile with maximum variation between different points $\left(1.50^{\circ} \mathrm{C}\right)$. These temperature variations were minimized in forced ventilated method by adequate air circulation within the pile. Regarding, the temperature distribution for the natural ventilated system (B), it can be noticed that the temperature gradient increased from the outsides (lower temperature) to the center (higher temperature) and bed of the onion pile with maximum variation between different points $\left(2.42^{\circ} \mathrm{C}\right)$. These temperature variations reached the maximum in natural ventilated system due to using of perforated pipes that exposed to the outside air temperature. that might be due to the temperature inside onion pile is different from that outside, pressure gradients are created because of a difference in air density, in addition to the inside temperature is warmer, the warm air will be displaced upwards by a buoyancy force. 


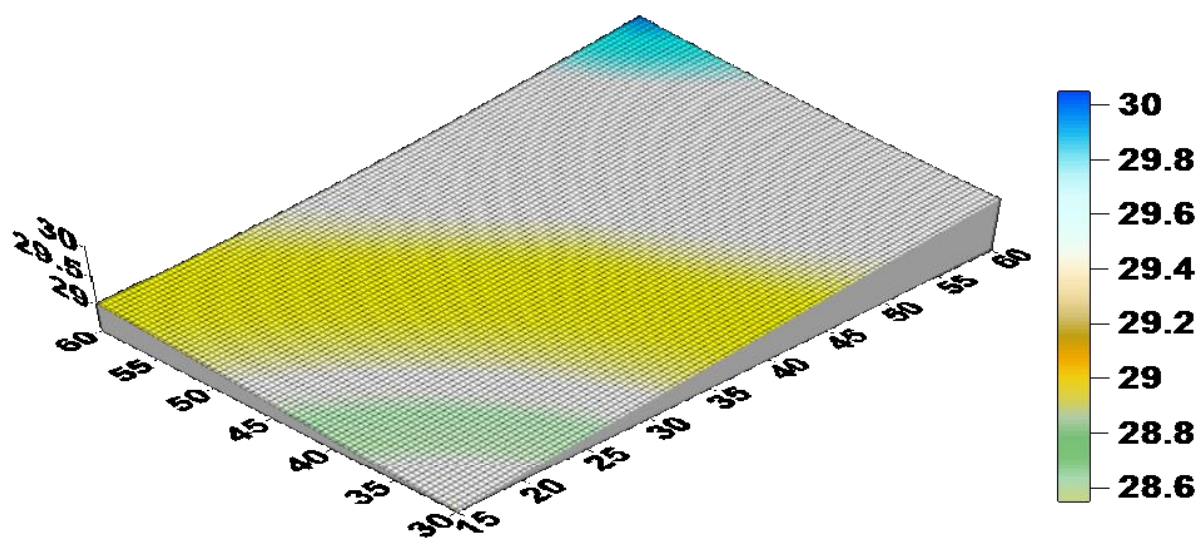

(A)
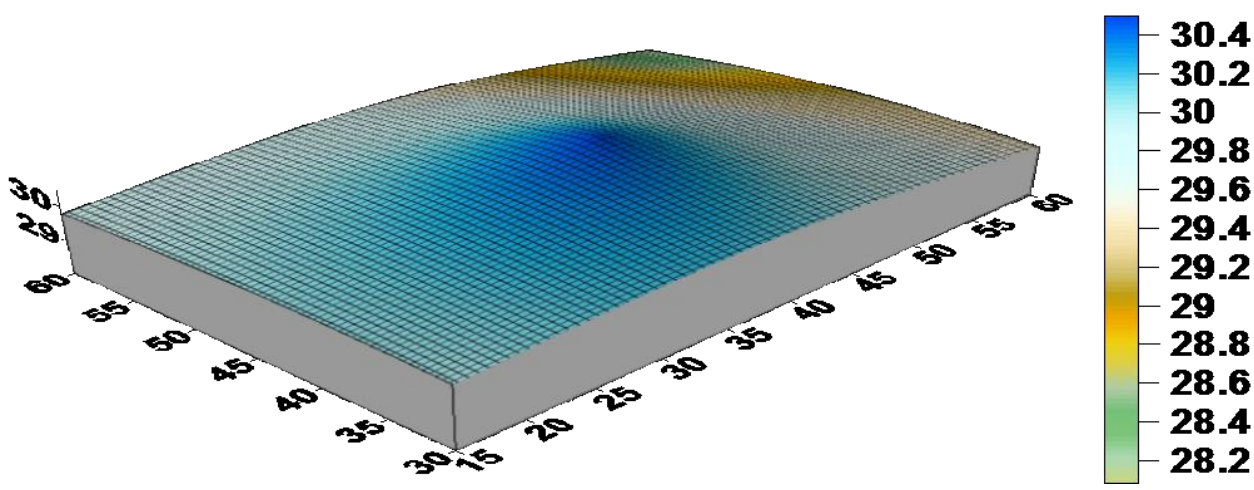

(B)
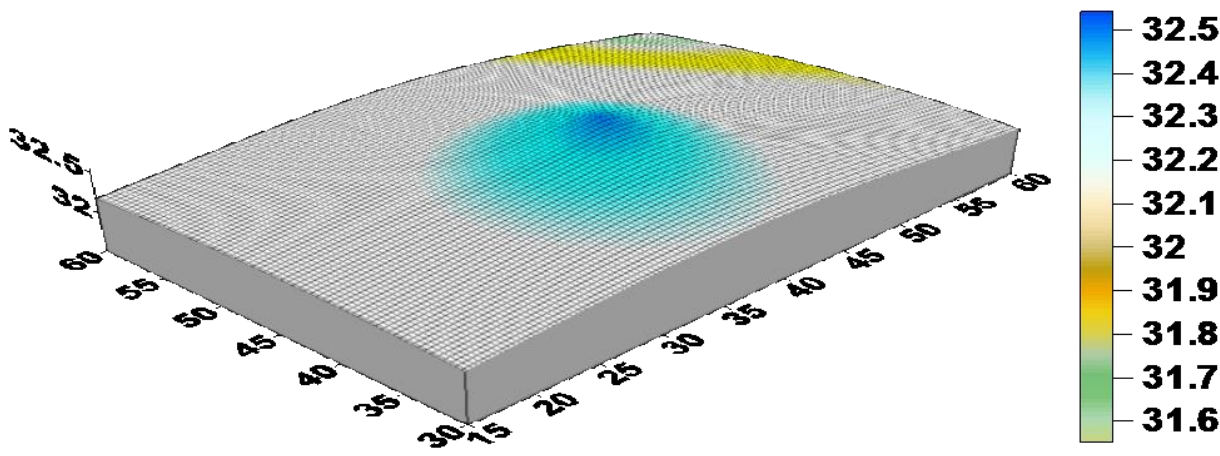

(C)

Figure 4. Temperature distributions at $12 \mathrm{pm}$ in forced ventilated (A), natural ventilated (B) and traditional storage systems (C) 
On the hand, the temperature distribution in the traditional storage system (C), it was found that, the temperature gradient increased from the outsides (lower temperature) to the bed (higher temperature) of the onion pile with maximum variation between different points $\left(0.99^{\circ} \mathrm{C}\right)$. The higher temperature that recorded during the day at different locations in onion pile, that might be due to the accumulation of temperature within the onion pile which results in increase of onion respiration rate.

\section{1-2 Relative humidity:-}

Data given in table 2 shows an example of the relative humidity recorded in the onion pile of storage systems under study (forced ventilated, natural ventilated and traditional storage systems) during the storage period. The average relative humidity values during the month of July were 73.77, 74.54 and $75.69 \%$ for forced ventilated, natural ventilated and traditional storage systems, respectively, while, they were $68.69,71.28$ and $74.64 \%$ during the month of August for the same previous order. On the other hand, the average relative humidity during the month of December were 70.90, 67.73 and $69.82 \%$ for forced ventilated, natural ventilated and traditional storage system, respectively, while, they were $67.93,71.23$ and $70.56 \%$ during the month of January for the same previous order.

Table 2: The average monthly relative humidity recorded in center of onion pile at different times of the day for the forced ventilated, natural ventilated and traditional storage systems

\begin{tabular}{|c|c|c|c|c|}
\hline Month & Time & $\begin{array}{c}\text { Forced } \\
\text { ventilated }\end{array}$ & $\begin{array}{c}\text { Natural } \\
\text { ventilated }\end{array}$ & $\begin{array}{c}\text { Traditional } \\
\text { storage }\end{array}$ \\
\hline \multirow{3}{*}{ July } & $12: 00 \mathrm{am}$ & 73.20 & 72.33 & 75.41 \\
\cline { 2 - 5 } & $6: 00 \mathrm{am}$ & 71.18 & 70.22 & 75.95 \\
\cline { 2 - 5 } & $12: 00 \mathrm{pm}$ & 74.96 & 72.88 & 75.98 \\
\cline { 2 - 5 } & $6: 00 \mathrm{pm}$ & 75.73 & 82.75 & 75.44 \\
\hline \multirow{5}{*}{ August } & $12: 00 \mathrm{am}$ & 68.27 & 71.68 & 74.55 \\
\cline { 2 - 5 } & $6: 00 \mathrm{am}$ & 68.58 & 70.49 & 74.89 \\
\cline { 2 - 5 } & $12: 00 \mathrm{pm}$ & 68.81 & 70.93 & 74.64 \\
\cline { 2 - 5 } & $6: 00 \mathrm{pm}$ & 69.10 & 72.01 & 74.48 \\
\hline December & $12: 00 \mathrm{am}$ & 65.87 & 68.06 & 69.99 \\
\cline { 2 - 5 } & $6: 00 \mathrm{am}$ & 65.22 & 67.20 & 69.57 \\
\cline { 2 - 5 } & $12: 00 \mathrm{pm}$ & 67.22 & 67.31 & 70.45 \\
\cline { 2 - 5 } & $6: 00 \mathrm{pm}$ & 85.28 & 68.34 & 69.26 \\
\hline January & $12: 00 \mathrm{am}$ & 67.615 & 72.32 & 71.08 \\
\cline { 2 - 5 } & $6: 00 \mathrm{am}$ & 67.74 & 70.59 & 70.03 \\
\cline { 2 - 5 } & $12: 00 \mathrm{pm}$ & 69.01 & 71.198 & 70.09 \\
\cline { 2 - 5 } & $6: 00 \mathrm{pm}$ & 67.34 & 70.81 & 71.05 \\
\hline
\end{tabular}


It could be seen that the variations between the average relative humidity recorded during the months of July, August, December and January were $1.92,5.95,3.17$ and $3.3 \%$ for the forced ventilated, natural ventilated and traditional storage system, respectively.

Figure 8 shows the relative humidity distribution for the forced ventilated, natural ventilated and traditional storage systems within the onion pile at various locations at $12 \mathrm{pm}$ during the first month of storage.

It can be noticed that the average relative humidity variations between the different points $2.7,5.25$ and $3.04 \%$ for the forced ventilated, natural ventilated and traditional storage systems, respectively. The relative humidity gradient increased from the outside (lower relative humidity) towards the bed (higher relative humidity) of the onion pile for the forced ventilated. These relative humidity variations were in contrary with temperature distribution as shown in figure 1 as a result of adequate air circulation within the pile. Also, the respiration of bulbs raised the temperature of air at the center of pile and, thus, lowered its relative humidity.

For natural ventilation system, the relative humidity gradient increased from the outside (lower relative humidity) towards the center (higher relative humidity) of the onion pile. The relative humidity gradient increased toward the center of pile because of the effect of natural movement of air which decreased the air temperature at the sides of onion pile and thus, reduced its relative humidity. In addition to the evaporative water from the onion at the center of pile reduced the temperature and increased its humidity.

On the other hand, the relative humidity gradient increased from the outside (lower relative humidity) towards the center (higher relative humidity) of the onion pile at traditional storage system, this was due to the higher rate of respiration at the center owing to the shape of the pile; i. e. more onion were present at the center of the pile than the sides, and thus, the moisture losses were observed at the center of the onion pile which tend to increase the relative humidity of the air. 

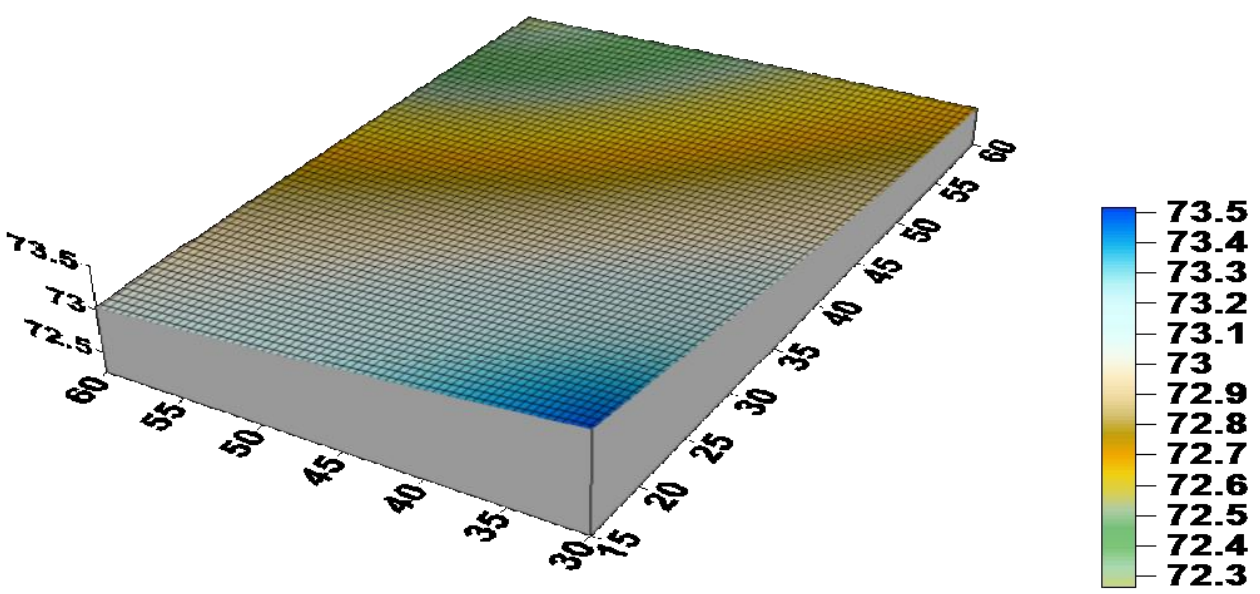

(A)
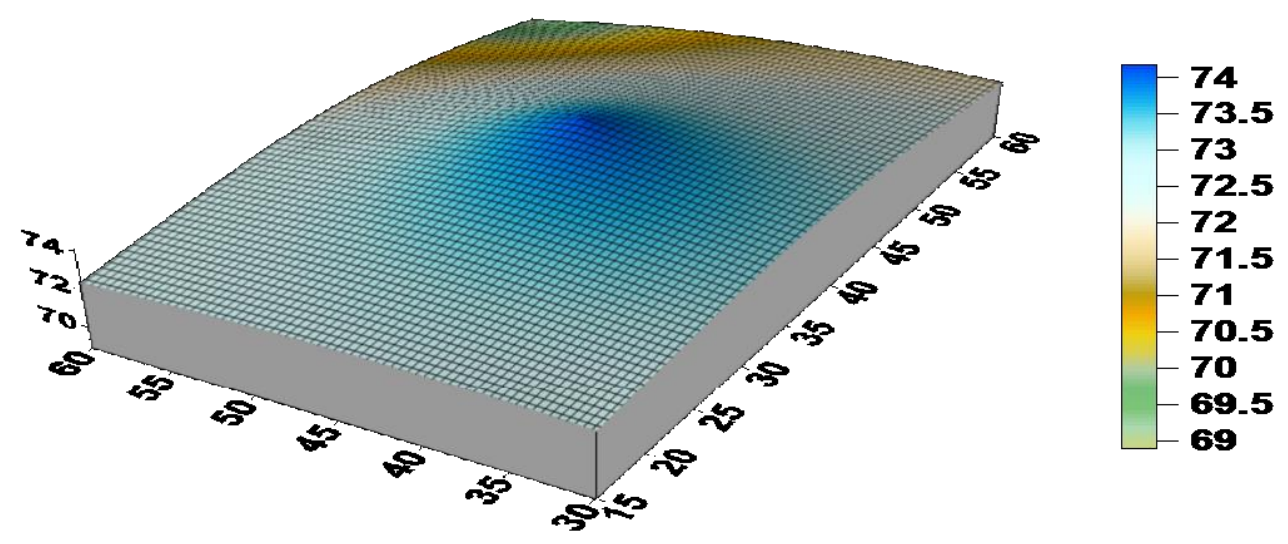

(B)

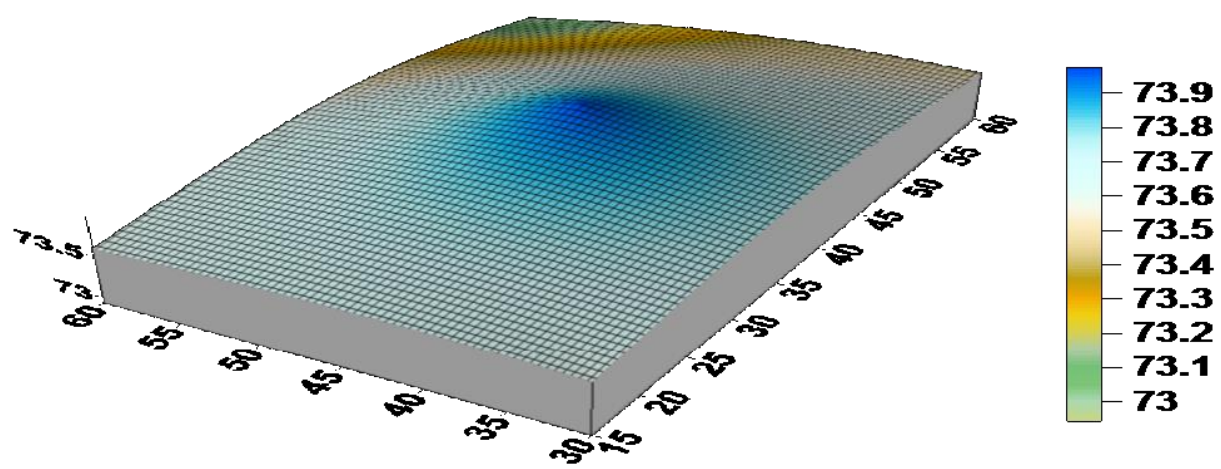

(C)

Figure 5 Relative humidity distributions at $12 \mathrm{pm}$ for the forced ventilated $(A)$, natural ventilated (B) and traditional storage system (C) 


\section{2- Onion properties:-}

Onion properties such as equatorial and polar diameters, hardness percentage, total soluble solids, dry matter and carbohydrate percentage were studied as the most important properties were affected by the storage conditions.

\subsection{Equatorial diameter :}

Table 3 shows the equatorial diameter changes of onion bulbs stored in three different storage systems (forced ventilated, natural ventilated and traditional storage systems) during seven months of storage periods. It could be seen that the equatorial diameter of onion decreased with storage periods, where they were $73.44 \pm 4.07,72.78 \pm 6.78$ and $73.11 \pm 6.09 \mathrm{~mm}$ during the first month of storage for forced ventilated, natural ventilated and traditional storage system, respectively. The reduction percentages were $1.06,1.06$ and $1.10 \%$ for forced ventilated, natural ventilated and traditional storage systems the end of storage periods.

Regression analysis was carried out to find a relationship between the equatorial diameter $(\mathrm{ED}, \mathrm{mm})$ changes and storage periods $(\mathrm{t}=$ months) for the storage systems under study, the most suitable forms were as follows:
$\mathrm{ED}=-0.5914(\mathrm{t})+73.793$
$\left(\mathrm{R}^{2}=0.948\right) \quad$ for forced ventilated system
$\mathrm{ED}=-0.6111(\mathrm{t})+72.951$
$\left(\mathrm{R}^{2}=0.944\right)$
for natural ventilated system
$\mathrm{ED}=-1.1193(\mathrm{t})+74.414$
$\left(\mathrm{R}^{2}=0.960\right)$
for traditional storage system

\section{Table 3. Equatorial and polar diameters changes during storage}

\begin{tabular}{ccccccc}
\hline \multicolumn{7}{c}{ Storage systems } \\
\hline $\begin{array}{c}\text { Storage } \\
\text { periods }\end{array}$ & $\begin{array}{c}\text { Equatorial } \\
\text { diameter } \\
(\mathrm{mm})\end{array}$ & $\begin{array}{c}\text { Polar } \\
\text { diameter } \\
(\mathrm{mm})\end{array}$ & $\begin{array}{c}\text { Equatorial } \\
\text { diameter } \\
(\mathrm{mm})\end{array}$ & $\begin{array}{c}\text { Polar } \\
\text { diameter } \\
(\mathrm{mm})\end{array}$ & $\begin{array}{c}\text { Equatorial } \\
\text { diameter } \\
(\mathrm{mm})\end{array}$ & $\begin{array}{c}\text { Polar } \\
\text { diameter } \\
(\mathrm{mm})\end{array}$ \\
\hline Jul. & 73.44 & 57.11 & 72.78 & 59 & 73.11 & 57.56 \\
Aug. & 72.22 & 55.89 & 71.44 & 58.33 & 71.78 & 55.56 \\
Sep. & 71.78 & 55.11 & 70.67 & 57.89 & 71.11 & 54.22 \\
Oct. & 71.67 & 54.67 & 70.44 & 56.89 & 70.56 & 53.33 \\
Nov. & 71.11 & 54.56 & 70.22 & 56.44 & 69.56 & 52.89 \\
Dec. & 70.44 & 53.78 & 69.44 & 56 & 67.22 & 50.44 \\
Jan. & 69.33 & 53.22 & 68.56 & 55.22 & 66.22 & 49 \\
\hline Means & 71.59 & 55.13 & 70.35 & 57.08 & 69.94 & 53.83 \\
SD & 3.93 & 4.70 & 6.516 & 3.64 & 5.12 & 4.68 \\
\hline
\end{tabular}




\subsection{Polar diameter}

Table 3 shows the polar diameter changes of onion bulbs stored in three different storage systems (forced ventilated, natural ventilated and traditional storage system) during seven months of storage periods. It could be seen that the polar diameter of onion decreased with storage periods, where they were $57.11 \pm 5.28,59.00 \pm 6.78$ and $57.56 \pm 2.92 \mathrm{~mm}$ during the first month of storage for forced ventilated, natural ventilated and traditional storage system, respectively. The reduction percentages were $1.07,1.06$ and $1.17 \%$ for the same previous order by the end of storage periods.

Regression analysis was carried out to find a relationship between the equatorial diameter $(\mathrm{PD}, \mathrm{mm})$ changes and storage periods $(\mathrm{t}=$ =months) for the storage systems under study, the most suitable forms were as follows:

$\begin{array}{lll}\mathrm{PD}=-0.5871(\mathrm{t})+57.254 & \left(\mathrm{R}^{2}=0.951\right) & \text { for forced ventilated system } \\ \mathrm{PD}=-0.6232(\mathrm{t})+59.603 & \left(\mathrm{R}^{2}=0.991\right) & \text { for natural ventilated system } \\ \mathrm{PD}=-1.3304(\mathrm{t})+58.607 & \left(\mathrm{R}^{2}=0.973\right) & \text { for traditional storage system }\end{array}$

\subsection{Onion hardness:}

Figure 11 shows the hardness values of onion bulbs stored under three different storage systems (forved ventilated, natural ventilated and traditional storage systems) during seven months. The results revealed that, the highest mean of hardness was recorded at forced ventilated (17.20kgf ), while the lowest mean was recorded at traditional storage system (16.90 kgf) where, the hardness of onion bulbs increased with increase of storage periods up to the middle of storage (16.43 to $18.40 \mathrm{kgf}$ ), while it decreased up to the end of the of storage periods (18.40 to $16.52 \mathrm{kgf}$ ). Hence the hardness value reached $16.86,16.47$ and $16.24 \mathrm{kgf}$ by the end of storage periods. This might be due to the reducing of moisture content during this period and increasing of dry matter content of onion bulbs, which leads to increase in hardness of bulbs, in addition to the regulation of the biochemical changes leading to increase hardness of onion bulbs at the end of storage periods. These results in confirm with observation of Satish and Ranganna ( 2002) who reported that, the hardness of onion bulb had significant increase $(9.75$ to $10.5 \mathrm{~kg} / \mathrm{cm} 2)$ with curing. 


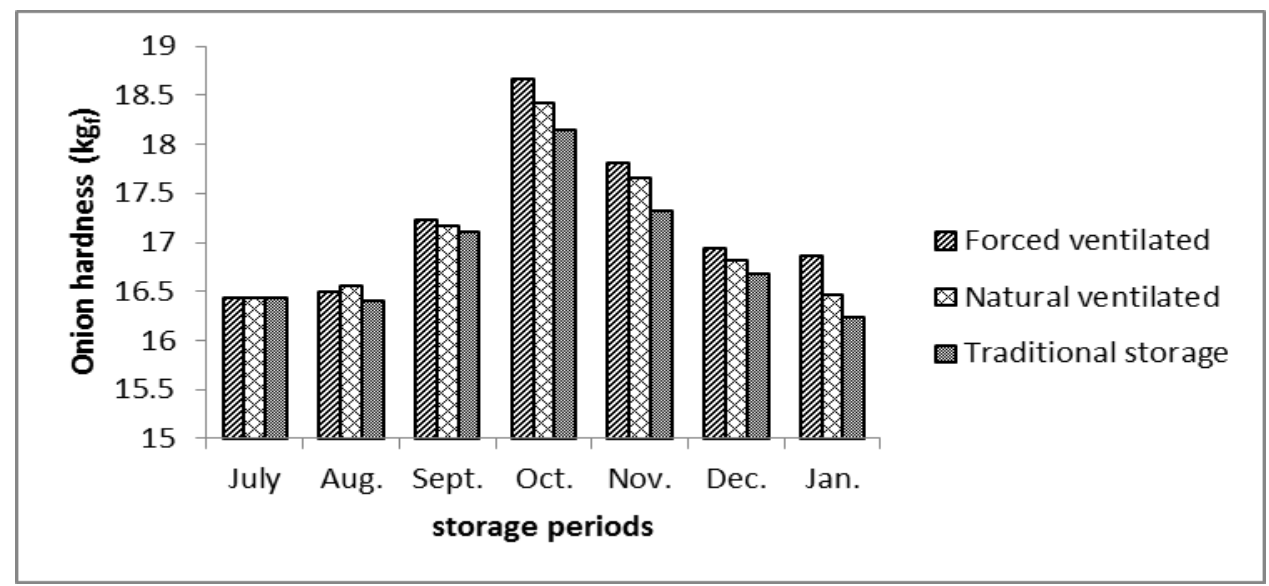

Figure 6 Hardness of stored onion bulbs under forced ventilation, natural ventilation and traditional systems.

\subsection{Total soluble solids (TSS) \%:}

Internal quality attributes of onion bulbs, such as soluble solid content (SSC) and dry matter (DM) content, are important quality indices for both consumers and the dehydration industry. Although the traditional destructive methods are accurate, they can only be used to measure limited number of samples and they are time consuming. Therefore, rapid and non-destructive internal quality evaluation techniques are in great demand.

Figure 12 shows total soluble solids percentage of onion bulbs during storage for seven months under three different storage systems (forced ventilated, natural ventilated and traditional systems), and the TSS content of the bulbs recorded 14.40, 13.55 and $13.47 \%$ for the onion stored under forced ventilated, natural ventilated and traditional systems, respectively. While the TSS percentage increased by increasing of storage periods and it reached the highest percentage $(17.07,15.10$ and $15.53 \%$, respectively) at the middle of storage and then reduced up to the end of experiment in all tested treatments, where they were $11.03,11.13$ and $10.67 \%$ during the first month of storage for the forced ventilated, natural ventilated and traditional system, respectively. While it reached $13.67,13.53$ and $13.67 \%$ by the end of storage periods for the forced ventilated, natural ventilated and traditional systems, respectively. These results are in close conformity with findings of Saimbhi and Randhawa (1982) and Patil and Kale (1988). 
These might be due to reducing of moisture content during this period and increasing of dry matter content of onion bulbs as presented in figure 13, which leads to changes in TSS content, in addition to the increase in TSS was mainly due to the conversion of polysaccharides into soluble form of sugars. The highest TSS content in onion bulbs was mainly attributed to the maximum conversion of polysaccharides into soluble forms of sugars. It may also, due to accumulation of more carbon dioxide and low oxygen content in the bulbs and this retardation effect on respiration ultimately reduces the transpiration process, which minimises the TSS loss. The increase in TSS content might also be attributed to the conversion of polysaccharides in to soluble forms of sugar (Singh and Dhankhar, 1992).

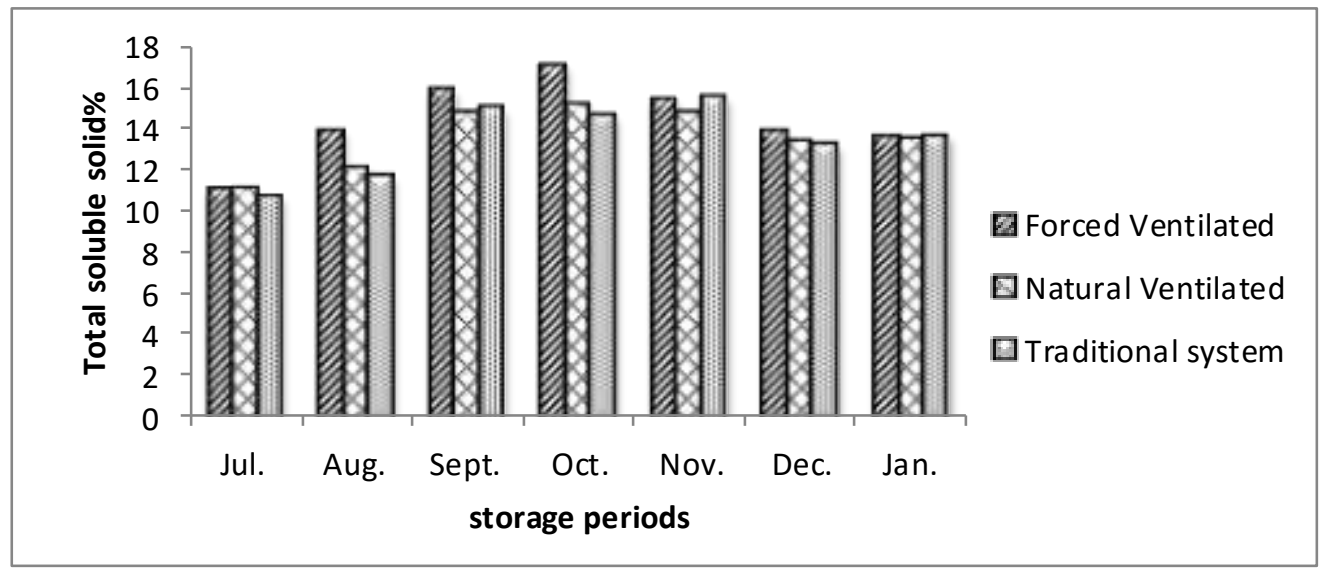

Figure 7 Total soluble solid percentages of onion stored under forced ventilated, natural ventilated and traditional storage systems

\subsection{Dry matter :}

Figure 13 shows the dry matter contents percentage of onion bulbs stored under three different storage systems (forced ventilated, natural ventilated and traditional storage system) during seven months of storage periods. The results revealed that, the dry matter contents of onion bulbs 15.94, 15.89 and $15.65 \%$ for the natural ventilated, forced ventilated and traditional storage systems, respectively. While the dry matter contents, increased with increase of storage periods up to the middle of storage periods and then decreased gradually up to the end of storage periods, where it recorded $14.69,14.91$ and $15.07 \%$ after the 
first month of storage for the forced ventilated, natural ventilated and traditional storage system, respectively. Where, it reached 16.58, 15.75 and $15.20 \%$ by the end of storage periods for the forced ventilated, natural ventilated and traditional storage systems, respectively. This agrees with moisture loss during this period which revealed increasing of dry matter content of onion bulbs and increased in chemical constituents in turn resulting in more dry matter content. These results in line with finding of Patil and Kale 1998, that the per cent dry matter and TSS increased during storage.

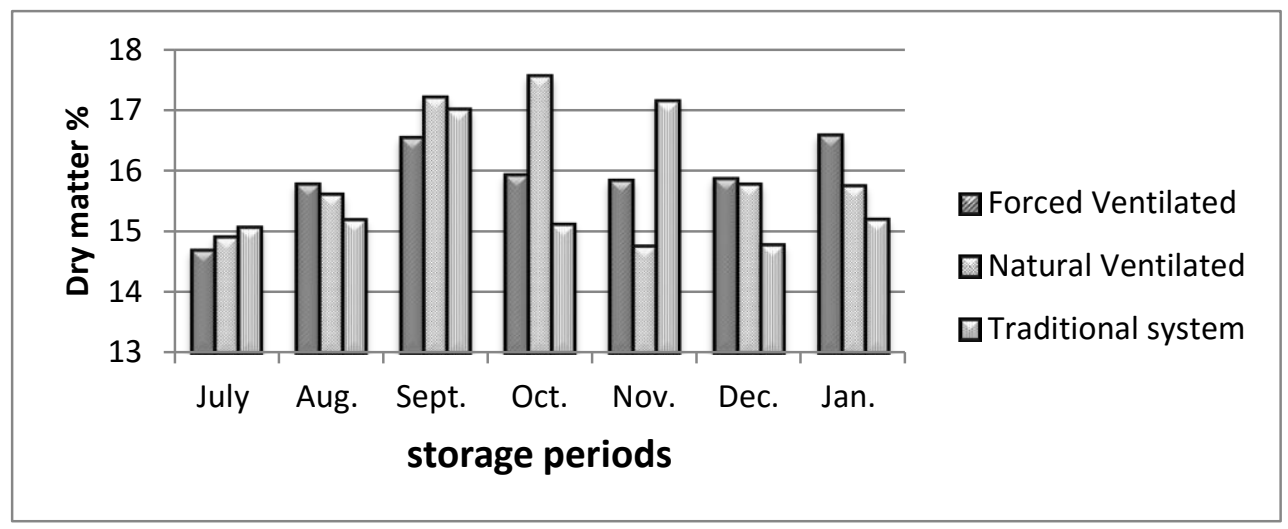

Figure 8 Dry matter percentage of onion stored under forced ventilated, natural ventilated and traditional storage systems.

\subsection{Carbohydrates percentage:}

Figure 13 shows the carbohydrates contents percentage of onion bulbs under three different storage systems (forced ventilated, natural ventilated and traditional storage system) during seven months of storage periods. The mean percentages were $8.08,8.05$ and $7.38 \%$ for the forced ventilated, natural ventilated and traditional storage system, respectively. The results also revealed that, the carbohydrate contents of onion bulbs after the first month of storage were $7.96,7.91$ and $7.80 \%$ for the natural ventilated, forced ventilated and traditional storage system, respectively. It reduced slightly with storage periods where it reached $7.80,7.57$ and $6.96 \%$ by the end of storage periods for the same order of treatments. The decreasing of carbohydrates percentage during storage could be reasonable due to the decreased of bulbs moisture content and increased in chemical constituents in turn resulting in decreasing the carbohydrates percentage. 


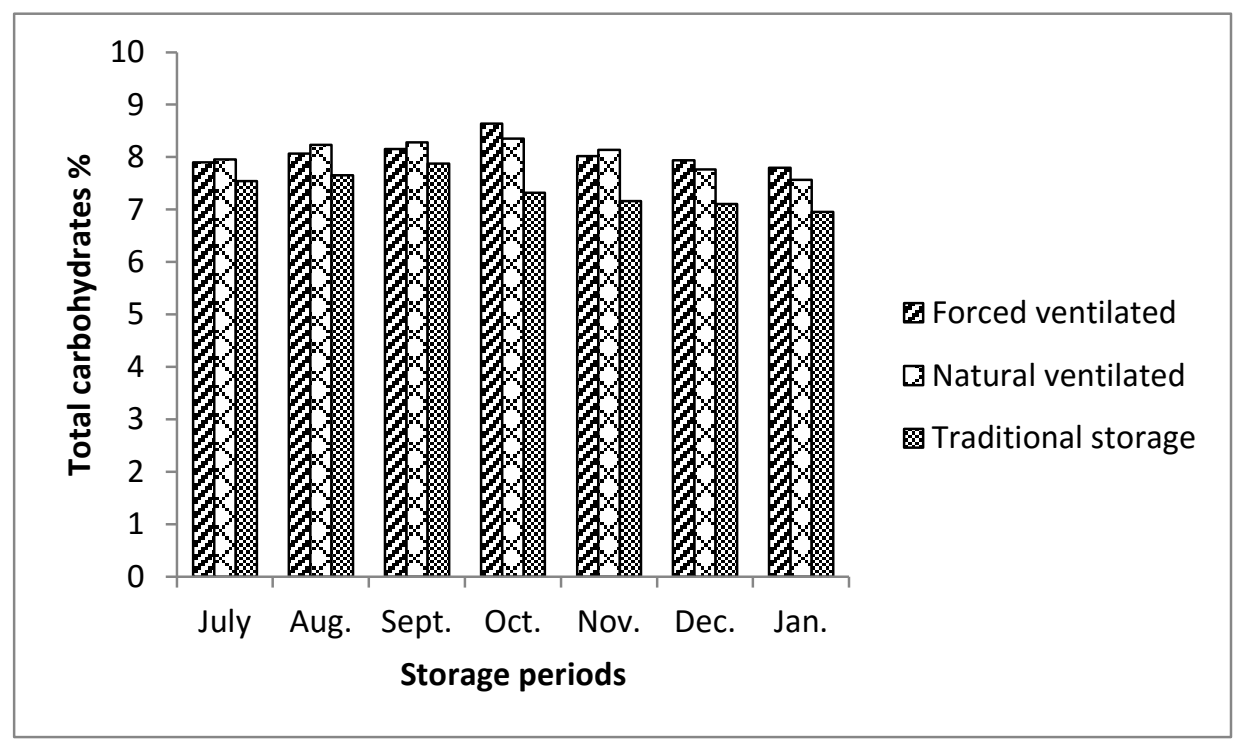

Figure 9 Total carbohydrate percentage of onion stored under forced ventilated, natural ventilated and traditional storage systems.

\section{CONCLUSION}

The effects of different storage conditions on properties of onions bulbs were studied and the obtained results could be summarized as follows:

1. The average temperature vareiations between different points within onion piles was $2.65{ }^{\circ} \mathrm{C}$ for the forced ventilated, in comparison with 4.83 and 6.74 ${ }^{\circ} \mathrm{C}$ for the natural ventilation and traditional systems, respectively.

2. The relative humidity variations were $3.78 \%, 6.08$ and $7.97 \%$ in forced ventilated, traditional and natural ventilation system, respectively.

3- Bulbs after 8 months of storage showed highest hardness value in forced ventilation (17.2 $\mathrm{kg}_{\mathrm{f}}$ )

4- The highest mean of dry matter contents recorded when the bulbs stored in natural ventilation $15.94 \%$.

5- The highest TSS obtained observed in forced ventilated was $14.40 \%$.

6- The higher carbohydrates percentage was recorded in forced ventilation $(8.077 \%)$.

For further use of these storage methods, natural ventilation with perforated pipes can be recommended at local community. The cost and benefits of these systems would require evaluation. Future storage bins should contain different 
air flow rates and less fluctuation would be shown in storage bin conditions and the onions should show improved storage characteristics, particularly few months of storage or more.

\section{REFERENCES}

A. O. A. C. (1995). Official Methods of Analyses, Kenneth Helrich Ed., 16th ed.

A.O. A. C. (1990). Official Methods of Analysis of Association of Official Agricultural Chemistry. 15th Ed.

Bhatnagar, A.K.; Tyagi, R.P.S. and Bansode, P.C. (1989). Handling, storage and marketing of onion. Dr. Panjabrao Deshmukh Krishi Vidyapeeth Research Journal,13(2): 135-139.

Chope, G.A.; Terry, L. and White, P. (2006). Effect of controlled atmosphere storage on abscisic acid concentration and other biochemical attributes of onion bulbs. Post harvest Biology and Technology 39: 233-242.

Corgan, J.N. and Kedar, N. (1990). Onion cultivation in subtropical climates, p. 31-48. In: H.D. Rabinowitch and J.L. Brewster (eds). Vol 2. Onions and allied crops. CRC Press, Boca Raton, Fla.

Croci, C.A.; Banek, S.A. and Curzio, O.A. (1995). Effect of gammairradiation on extending storage and chemical quality of onion (Allium cepa L.). Food Chemistry, 54(2): 151-154.

Currah, L. and Proctor, F. J. (1990). Onion in tropical regions. Natl. Res. Inst. UK. Bul. 35

Kaynas, K.; Besirli, G. and Damgaci, E. (1995). Using of bulk storage system on curing and storage potentials of onion bulbs; Sogan kurutma-olgunlastirma ve muhafazasinda yigin seklinde depolama sisteminin kullanim olanaklari Ataturk Central Horticultural Research Inst., Yalova (Turkey). pp. 32

Magadum, S.B. (1981). Genetic diversity in onion (Allium cepa L.) germplasm with special reference to storage quality. M.Sc. (Agri.) Thesis, Mahatma Phule Krishi Vidyapeeth, Rahuri. 
Maini, S.B. and Chakrabarti, A.K. (2000). Postharvest management of onions and garlic. Souvenir, National Symposium on Onion and Garlic Production and Postharvest Management: Challenges and Strategies, 1921 Nov. 2000, National Research Centre for Onion and Garlic, Rajgurunagar, Nasik, pp. 25-32.

Maw, B. W.; Hung, Y. C.; Tollner, E. W.; Smittle, D. A. and Mullinix, B. G. (1996). Physical and mechanical properties of fresh and stored sweet onions. Trans. ASAE, 39(2), 633-637.

Patil, J.D. and Kale, P.N. (1998). Storage studies in onion. Journal of Maharashtra Agricultural Universities, 12: 114-115.

Patil, R.S. (1983). Genetic variability in respect of storage quality of onion (Allium cepa L.). M.Sc. (Agri.) Thesis, Mahatma Phule Krishi Vidyapeeth, Rahuri.

Patil, R.S. and Kale, P.N. (1988). Biochemical changes during high temperature storage of bulbs of some onion cultivars. Journal of Maharashtra Agricultural Universities, 13(1): 108-109.

Raquel, P. F. and Maria, J. B. (2010). Texture of onions before and after freeze-drying. $5^{\text {th }}$ Central European Congress on food, $19^{\text {th }}-22^{\text {nd }}$ may. Bratislava, Slovake Republic. 1-5.

Rutherford, P.P. (1981). Some biological changes in vegetables during storage. Horticultural Abstracts, 11: 764 (8254).

Saimbhi, M.S. and Randhawa, K.S. (1982). Losses in white onion variety Punjab-48 under ordinary storage conditions as influenced by bulb size. Journal of Research Punjab Agricultural University, 19(3): 188-190.

Satish, S.V. and Ranganna, B. (2002). Effect of curing on the physical and mechanical properties of onion. Mysore Journal of Agricultural Sciences, 36: 266-269.

Singh, J. and Dhankhar, B.S. (1992). Biological changes of onion bulbs during storage as influenced by pre-harvest treatments. Vegetable Science, 19(1): 86-91. 


\section{الملخص العربى \\ تغير خصائص البصل تحت تأثير ظروف تخزين مختلفة

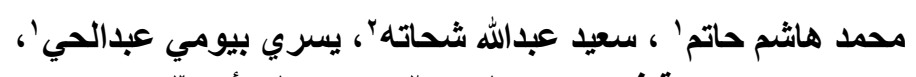

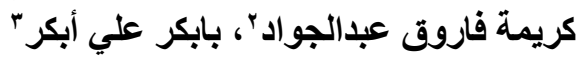

يتم تخزين البصل في مظلات تحت ظروف طبيعية في المناطق المدارية، مما يؤدي إلى فقد كبير أثناء التخزين. وتلعب ظروف التخزين دور كبير في تغير الخصائص الطبيعية و الكيميائية و الميكانيكية للبصل المخزن. الهدف من هذا البحث هو در اسة خصائص البصل تحت نأثثر فير فئرئ

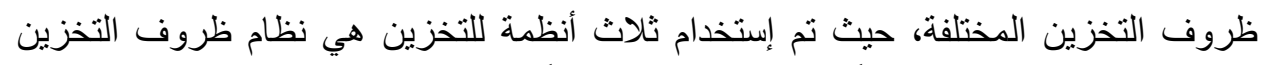

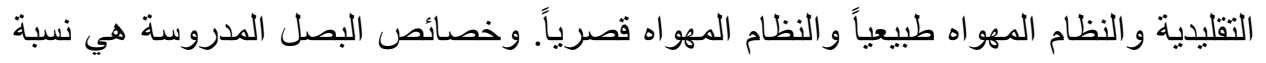

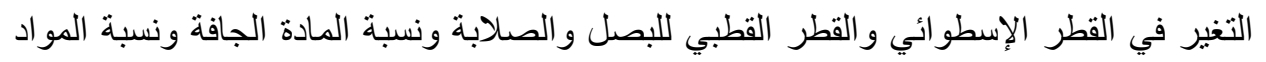

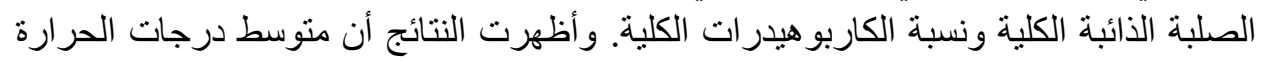

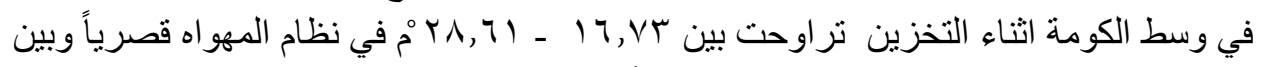

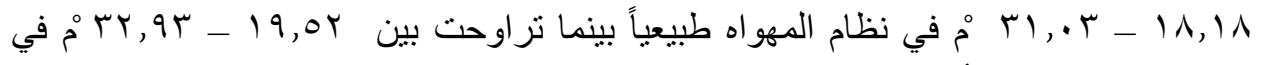

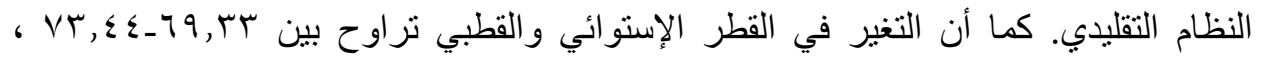

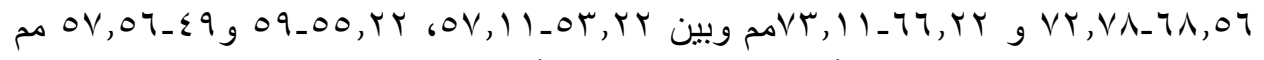

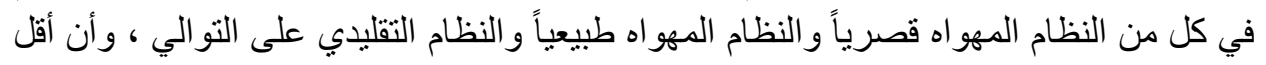

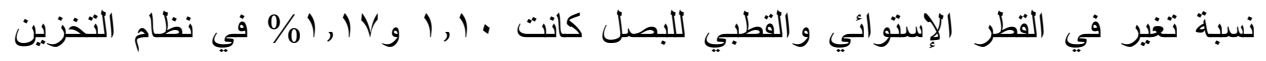
التقليدي على التوالي وأن أعلي قيمة للصلابة سجلت عند الإند البصل المخزن في النظام المهواه

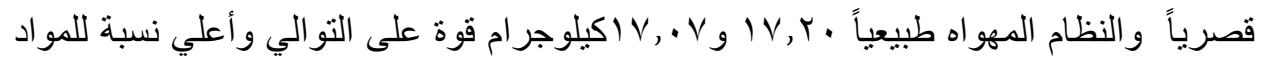

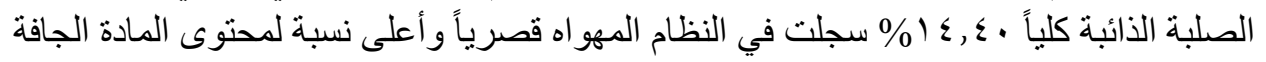

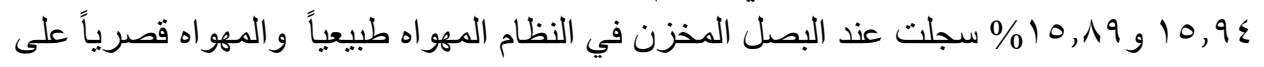

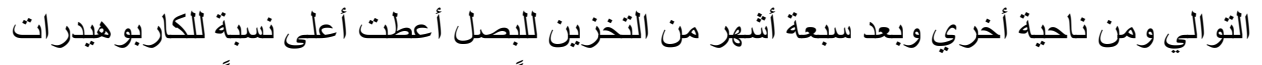

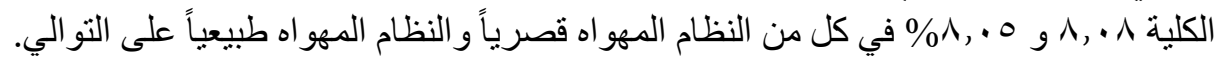

الكلمات الدالة: البصل، درجات الحرارة ، الرطوبة النسبية، تهوية طبيعية، تهوية قصرية، نظام

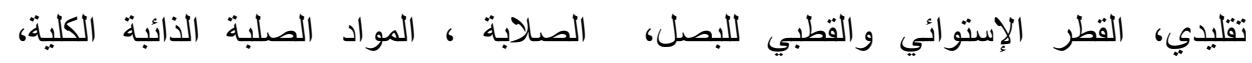
الكاربو هيدرات.

ا قسم الهندسة الزراعية ـ كلية الزراعة ـ جامعة القاهرة.

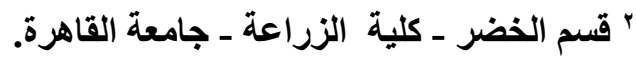

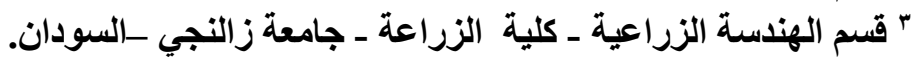

